\title{
Promoting Student Teachers' Content Related Knowledge in Teaching Systems Thinking: Measuring Effects of an Intervention through Evaluating a Videotaped Lesson
}

\author{
Frank Rosenkränzer ${ }^{1}$, Tim Kramer ${ }^{1}$, Christian Hörsch ${ }^{1}$, Stephan $_{\text {Schuler }}^{2} \&$ Werner Rie ${ }^{1}$ \\ ${ }^{1}$ University of Education, Freiburg, Germany \\ ${ }^{2}$ University of Education, Ludwigsburg, Germany \\ Correspondence: Frank Rosenkränzer, University of Education, Freiburg, Germany, Kunzenweg 21, 79117 \\ Freiburg. Tel: 49-761-68-2596. E-mail: frank.rosenkraenzer@ph-freiburg.de
}

Received: October 19, 2016

Accepted: November 1, 2016

Online Published: November 22, 2016

doi:10.5539/hes.v6n4p156

URL: http://dx.doi.org/10.5539/hes.v6n4p156

\begin{abstract}
The understanding of complex, dynamic and animate systems has a special standing in education for sustainable development and biology. Thus one important role of science teacher education is to promote student teachers' Content Related Knowledge (CRK) for teaching systems thinking, consisting of extensive Content Knowledge (CK) and well formed Pedagogical Content Knowledge (PCK). But the effective development of this knowledge is empirically uncertain. This article reports the effects of three different interventions (technical course, didactic course, mixed course) in promoting student teachers' reflective Content Related Knowledge for teaching systems thinking. Participants analyzed a videotaped lesson of 6th graders learning about the ecosystem lake and identified weak aspects in the teacher's CK and PCK. The results revealed that student teachers' reflective Content Related Knowledge for teaching systems thinking can be promoted in teacher education. The conclusion to be drawn from our findings is that a mixed course with equal technical and didactical input seems to be most effective in fostering student teachers' reflective Content Related Knowledge for teaching systems thinking.
\end{abstract}

Keywords: Pedagogical Content Knowledge, Content Knowledge, systems thinking, sustainable development, teacher education

\section{Introduction}

The teacher is the most important factor in student learning (Abell, 2007; Hattie, 2009). During the last 30 years, research in teacher education has searched for the essential characteristics possessed by a good teacher. To pursue this inquiry, researchers have used three different paradigms: the teacher personality paradigm, the process-product paradigm, and more currently the expert paradigm (Fischer et al., 2012). In early studies, Shulman and colleagues (Shulman, 1987) investigated teachers' professional knowledge. Research after Shulman $(1986,1987)$ began to draw a distinction between Pedagogical Knowledge (PK) and Content Related Knowledge (CRK). Content-Related Knowledge contains domain-specific subject-matter knowledge, also called Content Knowledge (CK), and the knowledge needed for teaching a specific content, called Pedagogical Content Knowledge (PCK). Pedagogical Knowledge (PK) refers to the non-content related educational knowledge of strategies and procedures to allow effective and undisturbed lessons. This latter type of knowledge goes beyond the subject matter and was not a part of our study.

In our larger study SysThema (systems thinking in ecological and multidimensional areas), we investigated in four substudies effects of different interventions on aspects of student teachers' teaching competencies. Figure 1 provides a summary of the different substudies in the SysThema study. This article focusses on student teachers CRK for teaching systems thinking. To evaluate student teachers professional knowledge in a situational context, we created a video-based measurement instrument. In comparison with other measurement instruments such as multiple-choice tests, open-ended pen and paper tests or teacher's observations, the evaluations of videotaped lessons offer the possibility to uncover the complexity of teacher's professional knowledge in action (Seidel \& Prenzel, 2007; Sherin \& van Es, 2009). 


\begin{tabular}{|c|c|c|c|c|}
\hline & $\begin{array}{l}\text { Student Teacher's } \\
\text { Content } \\
\text { Knowledge in } \\
\text { Teaching Systems } \\
\text { Thinking }\end{array}$ & $\begin{array}{l}\text { Student Teacher's } \\
\text { Pedagogical } \\
\text { Content } \\
\text { Knowledge in } \\
\text { Teaching Systems } \\
\text { Thinking }\end{array}$ & $\begin{array}{l}\text { Student Teacher's } \\
\text { Reflective } \\
\text { Content-Related } \\
\text { Knowledge in } \\
\text { Teaching Systems } \\
\text { Thinking }\end{array}$ & $\begin{array}{l}\text { Student Teacher's } \\
\text { Epistemic } \\
\text { Cognition in } \\
\text { Teaching Systems } \\
\text { Thinking }\end{array}$ \\
\hline Researcher & Fanta et al. (2016) & $\begin{array}{c}\text { Rosenkränzer, } \\
\text { Stahl, et al. (2016) }\end{array}$ & $\begin{array}{l}\text { Rosenkränzer, } \\
\text { Kramer et al. } \\
\text { (2016) }\end{array}$ & $\begin{array}{l}\text { Kramer et al. } \\
\qquad(2016)\end{array}$ \\
\hline $\begin{array}{l}\text { Dependent } \\
\text { Variable }\end{array}$ & $\begin{array}{c}\text { Content } \\
\text { Knowledge (CK) }\end{array}$ & $\begin{array}{c}\text { Pedagogical } \\
\text { Content } \\
\text { Knowledge (PCK) }\end{array}$ & $\begin{array}{c}\text { reflective } \\
\text { Content-Relatied } \\
\text { Knowledge (rCRK) }\end{array}$ & $\begin{array}{l}\text { Epistemological } \\
\text { Beliefs (EB) }\end{array}$ \\
\hline $\begin{array}{l}\text { Independent } \\
\text { Variable }\end{array}$ & $\begin{array}{l}\text { Three Different } \\
\text { Interventions }\end{array}$ & $\begin{array}{l}\text { Three Different } \\
\text { Interventions }\end{array}$ & $\begin{array}{l}\text { Three Different } \\
\text { Interventions }\end{array}$ & $\begin{array}{l}\text { Three Different } \\
\text { Interventions }\end{array}$ \\
\hline $\begin{array}{l}\text { Measurement } \\
\text { Instrument }\end{array}$ & Paper \& Pencil Test & Paper \& Pencil Test & $\begin{array}{l}\text { Analysing a Video } \\
\text { Vignette }\end{array}$ & Portfolio \\
\hline $\begin{array}{l}\text { Measurement } \\
\text { Points }\end{array}$ & $\begin{array}{c}\text { Pretest } \\
\text { Posttest } \\
\text { Follow-Up Test }\end{array}$ & $\begin{array}{c}\text { Pretest } \\
\text { Posttest } \\
\text { Follow-Up Test }\end{array}$ & $\begin{array}{c}\text { Pretest } \\
\text { Posttest } \\
\text { Follow-Up Test }\end{array}$ & $\begin{array}{c}\text { Pretest } \\
\text { Posttest } \\
\text { Follow-Up Test }\end{array}$ \\
\hline
\end{tabular}

Figure 1. Substudies in the larger SysThema study

\subsection{Teacher's Competencies}

The distinction of the different forms of teachers' CRK has been widely embraced in research on teacher knowledge (Abell, 2007; Borowski et al., 2012; Krauss et al., 2008; Kunter \& Baumert, 2013). The conclusion is that CK and PCK may be hypothesized to represent conceptually distinct forms of knowledge, with CK being the requisite for the development of PCK (e.g., Ball et al., 2005; Kunter \& Baumert, 2013). Given this current accepted model of teachers CRK, we characterise the different forms separately.

Many different conceptualisations of teacher's essential CK exist in the literature (e.g., Ball et al., 2005; Kunter \& Baumert, 2013). Nevertheless, common to all models is a deep understanding of CK, which goes beyond the common knowledge possessed by well-educated adult. This knowledge base implies not only knowing that something is so, but also the understanding why it is so (Shulman, 1986). How well teachers know their content "is central to their capacity to use instructional materials wisely, to assess students' progress, and to make sound judgments about presentations, emphasis, and sequencing" (Ball et al., 2005, p. 14). Thus it is not surprising that several studies provide evidence for a positive relationship between the teacher's CK and the respective students' learning progress (Abell, 2007; Baumert et al., 2009; Hashweh, 2005).

PCK "goes beyond knowledge of subject matter perse to the dimension of subject matter knowledge for teaching" (Shulman, 1986, p. 9). Hence, PCK is the "result of a transformation of knowledge from other domains" (Magnusson et al., 1999, p. 96), which implies both a CK base and a PK base. Further studies have emphasised the essential need for CK for the development of PCK (Abell, 2007; Borko \& Putnam, 1995; Grossman, 1990; Großschedl et al., 2014; Kunter \& Baumert, 2013; Magnusson et al., 1999; Park \& Oliver, 2008; Van Driel et al., 1998). Teachers possessing extensive PCK know the most powerful forms of representations and the most powerful analogies, illustrations, examples, explanations, and demonstrations. PCK also includes the knowledge and understanding of factors that make the learning of a special topic easy or difficult (Shulman, 1986). These components are essential parts of PCK and are included in almost every conceptualisation. Knowledge of curriculum and knowledge of educational ends are two additional forms considered in many conceptualisations of PCK. An overview of individual conceptualisations is given by Park and Oliver (2008), and Van Driel, Verloop, and De Vos (1998). Overall, research in teacher education has explored the described forms of CRK as main factors for effective teaching and learning (Krauss et al., 2008; Baumert et al., 2009). 


\subsection{Knowledge for Teaching Systems Thinking}

Future teachers need a well-formed CRK to be able to teach about the complexity of a world getting increasingly global and interconnected and to foster an understanding of complex and dynamic systems. A system is defined as a "set of elements standing in interrelation" (Bertalanffy, 1968, p. 55). The system theory approach explains the behavior of complex systems, e.g., of ecosystems from a certain point of view. The aim to promote systems thinking in school is based inter alia on the assumption that students can only actively participate in sustainable development when they are able to identify and to understand complex, global relations using the methods of system theory (Riess \& Mischo, 2010). Our consideration of systems thinking is based on the definition of Riess and Mischo (2010, p. 707):

We see systems thinking as the ability to recognize, describe and model (e.g., to structure, to organize) complex aspects of reality as systems. Another important aspect of systems thinking is the ability to identify important elements of the system and the varied interdependency between these elements. Other key aspects are the ability to recognize dimensions of time dynamics, to construct an internal model of reality and to make prognoses on the basis of that model.

To conceptualise this definition in more detail, Rieß and his research group developed a heuristic competence model in systems thinking and used it in the survey of Bräutigam (2014). Bräutigam had investigated the systems thinking skills of 7th graders and used a three dimensional competence model. Errors and insufficiencies of the competence model noted in her study were discussed and revised. On the basis of further studies in the literature in systems sciences (e.g., Matthies et al., 2001), the analysis of other competence models in systems thinking (Ben-Zvi Assaraf \& Orion, 2005; Evagorou et al., 2009; Rempfler \& Uphues, 2011; Verhoeff, 2003), including several discussions with researchers in environmental systems sciences, we added an further aspect to illustrate the relevance of evaluating the model and validating the results. Thus the current heuristic competence model of systems thinking (Rieß, Schuler, \& Hörsch, 2015) includes four dimensions, each divided into four sub-capabilities (see Figure 2).

\begin{tabular}{|c|c|c|c|c|}
\hline Competence Dimensions & Sub-Capability 1 & Sub-Capability 2 & Sub-Capability 3 & Sub-Capability 4 \\
\hline $\begin{array}{l}\text { Dimension 4: } \\
\text { evaluation of system models }\end{array}$ & $\begin{array}{l}\text { determining the structural validity } \\
\text { of system models }\end{array}$ & $\begin{array}{l}\text { determining the validity of system } \\
\text { models }\end{array}$ & $\begin{array}{l}\text { determining the validity of the } \\
\text { application }\end{array}$ & $\begin{array}{l}\text { determining the uncertainty of a } \\
\text { forecast }\end{array}$ \\
\hline $\begin{array}{l}\text { Dimension 3: } \\
\text { solving problems } \\
\text { using system models }\end{array}$ & $\begin{array}{l}\text { assessing the need of using a } \\
\text { system model for processing a } \\
\text { present problem }\end{array}$ & $\begin{array}{l}\text { assessing the type of system } \\
\text { model (e.g. quantitative vs. } \\
\text { qualitative) that is required to } \\
\text { process a problem }\end{array}$ & $\begin{array}{l}\text { giving explanations, making } \\
\text { predictions and designing } \\
\text { technologies based on qualitative } \\
\text { system models }\end{array}$ & $\begin{array}{l}\text { giving explanations, making } \\
\text { predictions and designing } \\
\text { technologies based on quantitative } \\
\text { system models }\end{array}$ \\
\hline $\begin{array}{l}\text { Dimension 2: } \\
\text { modeling systems }\end{array}$ & $\begin{array}{l}\text { determining system elements, } \\
\text { interactions, subsystems, system } \\
\text { boundaries, system hierarchies } \\
\text { and the model purpose }\end{array}$ & $\begin{array}{l}\text { understanding and reflecting a } \\
\text { complex system with the help of a } \\
\text { text field or a word model }\end{array}$ & $\begin{array}{l}\text { reading and understanding } \\
\text { qualitative system models, } \\
\text { Construct influence diagram }\end{array}$ & $\begin{array}{l}\text { reading and constructing } \\
\text { quantitative system models }\end{array}$ \\
\hline $\begin{array}{l}\text { Dimension 1: } \\
\text { declarative / conceptual systems } \\
\text { knowledge }\end{array}$ & $\begin{array}{l}\text { basic knowledge of systems theory } \\
\text { (system concept, system structure, } \\
\text { system behavior, sub-systems) }\end{array}$ & $\begin{array}{l}\text { knowledge of areas that can be } \\
\text { considered as systems (also } \\
\text { knowledge of simple and complex } \\
\text { systems) }\end{array}$ & $\begin{array}{l}\text { knowledge of system hierarchies } \\
\text { (e.g., cell, tissue, argan, organism, } \\
\text { population, biocenosis, ecosystem, } \\
\text { biosphere) }\end{array}$ & $\begin{array}{l}\text { knowledge of properties of } \\
\text { complex systems (structural and } \\
\text { dynamic complexity, non-linearity, } \\
\text { emergence, ....) }\end{array}$ \\
\hline
\end{tabular}

Figure 2. Freiburg heuristic competence model of systems thinking

The conceptualisation of student teachers' CRK for teaching systems thinking is composed of CK for teaching systems thinking and PCK for teaching systems thinking, which are elaborated in the following section.

\subsection{Conceptualisation of Teacher's CK about Ecology and Systems Sciences}

When conceptualising teachers' CK for teaching systems thinking, we orientated on the described heuristic competence model of systems thinking (see Figure 2). However when theorising about CK, we need to distinguish static knowledge about ecological facts and concepts and principles that apply within systems sciences (declarative knowledge) from procedural knowledge, which contains actions or manipulations that are valid within the systems sciences (De Jong \& Ferguson-Hessler, 1996). Declarative knowledge about ecology and systems sciences is described in Dimension 1 (declarative/conceptual systems knowledge) and Dimension 2 
(modeling systems). Dimension 1 includes basic knowledge of systems theory, knowledge of areas that can be considered as systems, knowledge of systems hierarchies and knowledge of properties of complex systems. Competences in modeling systems are required in Dimension 2, such as determining system elements, interactions and subsystems but also the understanding of and the ability to reflect on complex systems with the help of a text field or a word model, as well as reading and understanding both qualitative and quantitative system models. Procedural knowledge in solving problems by using system models is listed in the third dimension. Teachers need to know how to assess whether a system model is useful for processing a problem and whether a quantitative or a qualitative model is required, as well as knowing how to provide explanations, make predictions, and design technologies based on these models. Also required in teachers' CK is the ability to evaluate system models according to their validity (e.g., in structure and in application) and the uncertainty of a prediction.

\subsection{Conceptualisation of PCK for Teaching Systems Thinking}

CRK includes the special knowledge for teaching, PCK, which goes beyond subject matter knowledge. Based on the approaches described, we conceptualized PCK for teaching systems thinking in three facets, as follows:

Knowledge of Curriculum and Educational Ends includes the "teacher's knowledge of the goals and objectives for students" (Magnusson et al., 1999, p. 103) in promoting systems thinking. The teacher needs to know about the heuristic competence model in teaching systems thinking (see Figure 2) and they also need to know the competencies that are essential for teaching. Peterson and Treagust (1995) found that knowledge of curriculum was an essential part of pre-service teachers' pedagogical reasoning about lesson planning and instruction. The teacher, possessing a substantial PCK, knows the curriculum and educational ends for teaching.

Knowledge of Instructional Strategies means knowing about topic specific methods, representations, examples, models and activities (Abell, 2007; Shulman, 1986). It includes knowledge of methods as well as their reasonable and productive use (Magnusson et al., 1999) with the goal of fostering systems thinking. Teachers know the "most powerful strategies" (Shulman, 1986, s. 9) and their use for fostering systems thinking. They have a repertoire of methods for promoting declarative and conceptual systems knowledge such as working with worksheets about systems sciences or using of educational films about ecosystems and their integration in lessons. They know the best teaching methods and strategies to enable pupils to model systems, solve problems and evaluate models.

Knowledge of Students' Understandings characterises the ability of teachers to understand the perspective of their pupils' position. From this perspective, teachers can discern pupils' correct and incorrect conceptions concerning systems thinking as well to assess "what makes the learning of specific topics easy or difficult" (Shulman, 1986, p. 9). Substantial and correct understanding in systems thinking is needed to be able to not only recognize that a pupil's answer might be wrong but also to analyze the source of the error.

The relevance of teachers' CRK has been discussed in several studies, particularly in mathematics and science teaching (Ball, Lubienski, \& Mewborn, 2001; Krauss et al., 2008; Großschedl et al., 2014). However, the effective development in teacher education with the focus on the key comptence in sustainable development of CRK for systems thinking, remains empirically unclear.

\section{Method}

\subsection{Context of the Study and Research Question}

The goal of the present study was to evaluate the effects of three different interventions in teaching systems thinking for student teachers at the Universities of Education in Freiburg and in Ludwigsburg (Germany) during the summer semester 2013. We used a quasi-experimental approach (Shadish et al., 2002) with three treatment courses and a control group to examine effects of different inputs on the dependent variable, student teachers' CRK. Every course consisted of 14 sessions of 90 minutes each. All of the courses had two common goals. First, the courses were designed to enhance student teachers' ability in systems thinking, that is, their ability to solve complex dynamic problems within the context of sustainable development (acquiring CK). Second, the participants should gain the ability to teach systems thinking effectively (acquiring PCK). In Course 1, student teachers received a more technically oriented input, whereas they received a more subject-related didactic input in Course 2. Course 3 combined technical and subject-related didactic content in almost equal proportions. The Control Group received no intervention. We used these variations of the intervention to clarify which combination of technical and subject related didactic content helps student teachers most effectively in teaching systems thinking. 


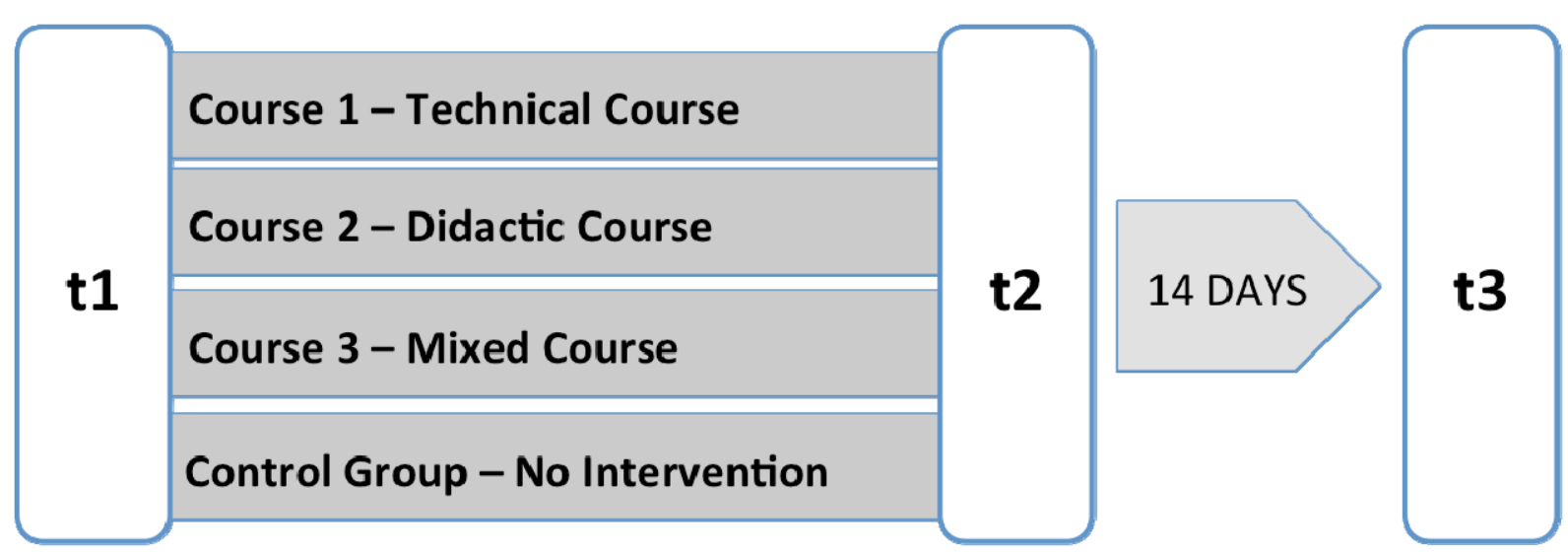

Figure 3. Overview of the study (we used the video in all measurements to capture student teachers' reflective

CRK)

This design opens the possibility to "test descriptive causal hypotheses about manipulable causes" (Shadish et al., 2002 , p. 14). For each group, CRK for teaching systems thinking (dependent variable) was measured before the intervention (pretest, $\mathrm{t} 1$ ), and after the intervention (posttest, $\mathrm{t} 2$ ). Two weeks after the intervention, we measured again in a follow-up test (follow up test, t3).

As an alternative to traditional pen \& paper tests, videos showing an authentic situation in class are commonly used. The participants' task was to analyze the presented video and to note key aspects indicating good teaching, such as respecting pupils' cognitions or using instructional strategies adequately. The ability to judge the teaching in the video required that the teacher had a professional vision (Todorova, Sunder, Steffensky, \& Möller, 2014), that is, the ability to identify and interpret important aspects in educational situations. Professional vision functions as a mediator between theory and the teacher's practice (Schmelzing et al., 2013) and is an essential requirement for the teacher's adaptive action (Bromme, 2008; Sherin \& van Es, 2009). Schmelzing et al. use the term reflective professional knowledge. This knowledge is necessary for identifying habits based on pedagogical actions and for analyzing the effects of teacher actions (Schmelzing et al., 2013).

Based on this theoretical framework, we postulated the following questions:

(1) Is there an intervention effect in student teachers' reflective CRK in evaluating a lesson with the goal of fostering systems thinking?

(2) Are there identifiable differences in the intervention courses? Which seminar is most effective in promoting student teachers' reflective CRK in evaluating a lesson with the goal of fostering systems thinking?

\subsection{Participants}

We offered courses in geography and biology at universities of education in Germany. These courses were essential seminars in student teachers' curriculum and were labeled without describing any specific information about the content. The participants (108 student teachers) selected the intervention courses blindly. All the participants had gained the German Abitur (A level degree qualifying for university admission), studied on average in their 6th semester, and were aged between 20 and 47 years (see table for descriptive statistics). The low representation of males corresponds with the usual relations of female and male student teachers in German universities of education.

Table 1. Descriptive statistics of intervention and control groups

\begin{tabular}{lcccc}
\hline & Control Group & (1) Technical Course & (2) Didactic Course & (3) Mixed Course \\
\hline $\mathrm{N}$ & 37 & 23 & 25 & 23 \\
Male/Female & $4 / 33$ & $5 / 18$ & $0 / 25$ & $6 / 17$ \\
$\varnothing$ grade & $2.38(S D=0.54)$ & $2.57(S D=0.45)$ & $2.46(S D=0.39)$ & $2.50(S D=0.42)$ \\
$\varnothing$ age & $23.68(S D=2.41)$ & $23.41(S D=1.79)$ & $24.64(S D=5.03)$ & $24.52(S D=4.57)$ \\
$\varnothing$ semester & $6.19(S D=2.03)$ & $5.78(S D=1.95)$ & $6.68(S D=1.67)$ & $6.09(S D=1.38)$ \\
\hline
\end{tabular}




\subsection{Instruments}

To measure student teachers' reflective CRK, we developed a video with an associated booklet. While content of the intervention courses was about the ecosystem forest and its complexity and dynamic in a sustainable development, the video to measure student teachers' reflective CRK was about the ecosystem lake, which required the use of systems thinking in a transferred content. The target pupils were 6th graders, because they learned about complex and dynamic ecosystems for the first time in German secondary school curriculum. The student teachers were introduced to the associated booklet about the procedure and the goals of the lesson. We installed six mistakes in the video vignette, three in each form of CRK.

The procedure begins with an introduction to the ecosystems of a lake. The teacher provides an incorrect definition of a system (first CK aspect), labels the connections and interactions incorrectly (second CK aspect) and demonstrates the complexity of a system mainly as a food web (third CK aspect). In further situations, the teacher also shows three critical weaknesses in PCK. The teacher assumes pupils know the term system in ecological sciences when the topic is introduced (first PCK aspect). After the pupils read the incorrect definition already written on the board, they are asked to identify some interactions within the ecosystem of lakes. The teacher notes all the mentioned interactions on the board regardless of whether they are right or wrong (second PCK aspect). The interaction between pollywogs and frogs is labeled become to and the interaction between water lilies and water plants is labeled with the term belong to. Thus, a confusing map with many labeled connections and interactions arise. The pupils are encouraged to copy the model to their notebooks. In the end, the planned goals of introducing systems thinking with the example of the ecosystem lake and gaining basic knowledge of the system sciences by constructing a simple system model are not achieved (third PCK aspect). After watching the video, student teachers were requested to analyze and assess the lesson from a professional point of view and to make notes about the errorneous situations. Figure 4 shows an overview of the mistakes.

To achieve satisfactory content validity, we asked a number of experts (researchers in the didactics of biology and geography) to investigate the video in an online survey. After the experts examined the video, they were asked to mark the critical aspects in the online option list. The experts had the option to make suggestions to optimise the measurement. We analysed both, the marked options in compliance with the critical aspects and the experts' suggestions (e.g., omitting multiple choices). On the basis of these analyses, we improved the measurement instrument by omitting the choices to avoid anticipations and coincidences.

\begin{tabular}{|ll|}
\hline Errors related to Teachers' Content Knowledge (CK) & Errors related to Teachers' Pedagogical Content Knowledge (PCK) \\
\hline Incorrect definition of a system & $\begin{array}{l}\text { The assumption that pupils know the term system in ecological } \\
\text { sciences }\end{array}$ \\
\hline Incorrect labeling of the connections and interactions & $\begin{array}{l}\text { Confusing map with many labeled connections and interactions } n \\
\text { the board }\end{array}$ \\
\hline Complexity of a system is demonstrated mainly as a foodweb & The planned goals are not achieved \\
\hline
\end{tabular}

Figure 4. Overview of the mistakes in the video vignette

\subsection{Intervention}

Within the larger study, SysThema, we designed three different courses for student teachers in the subject areas of biology and geography (described more in detail in Rieß, Schuler, \& Hörsch, 2015). The didactic structure of all units in the intervention follows the Model Of Problem-Oriented Learning and Teaching (MOPOLT), created by Rieß and Mischo (2016). At the beginning of each unit, the student teachers were introduced to the goals of the session and their importance. They began by working on a task, for example analyzing a complex problem within a genuine case example or creating an effective lesson about systems thinking. The student teachers became engaged in the given task, and while trying to solve the problem, they realized their need for further knowledge and competencies. The lecturer as an expert demonstrated the method developed by scientists to solve the problem and explained the thoughts behind each step. The student teachers were introduced into the expert culture by authentic activities and specific instruction. Over the duration of the unit, the student teachers worked alone or in small groups on additional tasks similar to the first task while progressively learning to solve them independently. The results and the applied strategies were presented and reflected in class. Finally, the 
student teachers were given the opportunity to further practice and to transfer and apply the gained competencies in other areas.

In the first units, specific knowledge about systems was imparted in the following three topics: 1) introduction into systems sciences and analysis (Bossel, 2007; Matthies et al., 2001); 2) forest ecosystem; and 3) syndromes of global change, for example deforestation, soil degradation, overfishing, climate change, and overfishing according to the syndromes concept (Schellnhuber et al., 1997). Later in the courses, the case examples, systems modeling, systems analysis, and lesson planning were related to these topics. After providing a common foundation, the three courses diverged with regard to their technical and subject-related didactic proportions.

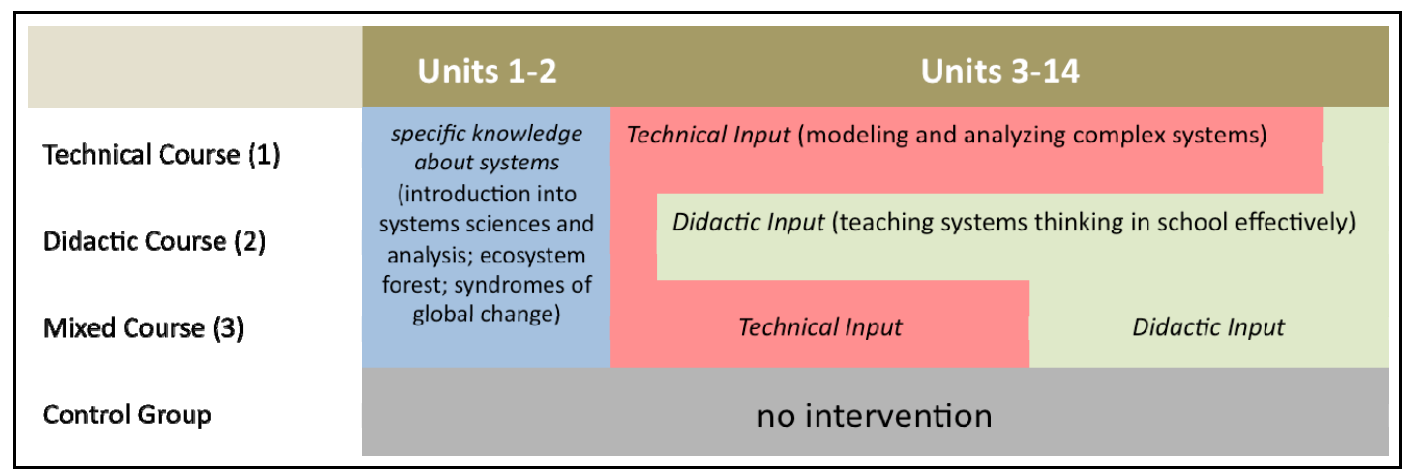

Figure 5. Overview about the intervention

\subsubsection{Intervention 1-Technical Course}

In the Technical Course, the different systems were modeled and analyzed with increasing autonomy and on a higher level of systems science. For example, the student teachers learned to construct an influence diagram such as a qualitative system model, consisting of system elements (nodes) and system relationships (influences, arrows). Quantitative system models were also constructed and simulated with software. The student teachers learned to analyze complex systems (e.g., the issue with overfishing; Kropp et al., 2006) to be able to provide explanations and to make predictions with regard to the behavior of a system and to find appropriate measurements to influence the system behavior in a positive way (e.g., calculating fishing quotas for sustainable fishing in a fishery model; Bossel, 2007). Furthermore, the student teachers evaluated system models, determined their validity, and developed an awareness of their uncertainty. The students determined the sensitivity of the system model and created a range of possible future scenarios, and then they tested their implications by running the simulation under different conditions. How to foster pupils in systems thinking in school and how to create an appropriate learning environment was less of a focus in the Technical Course.

\subsubsection{Intervention 2-Didactic Course}

The more subject-related didactic course emphasized the effective teaching and learning of systems thinking in school. The student teachers approached the question of what is actually meant by systems thinking. They compared and reflected on different conceptualizations found mainly in the German literature (e.g., Rieß \& Mischo, 2010). The reasons for teaching systems thinking to pupils were discussed in depth. The participants formulated learning goals on different levels, compared them with the existing competence model (see Figure 2; cf. Rieß, Schuler, \& Hörsch, 2015), and created different tasks for measuring the competence of systems thinking. The student teachers learned about several teaching methods (e.g., Schuler, 2012), tested them, and planned numerous lessons. Scientific methods were considered, implemented, and reflected on as possible teaching methods. They also learned about pupils' preconceptions of systems (e.g., Jelemenska \& Kattmann, 2008), and they thought about how to promote learning by engaging the pupils. Systems modeling and analysis received less attention and was practiced mostly with qualitative system models only. The student teachers worked with fewer case examples and were more guided throughout the process. For example, they operated with simpler, ready-made simulation models on the computer. Most importantly, the participants adopted the perspective of a teacher and evaluated, for example, the impact analysis as a potential teaching method. 


\subsubsection{Intervention 3-Mixed Course}

The third course combined technical and subject-related didactic content in almost equal proportions. The Mixed Course was designed from central components out of both courses described above. The participants almost worked on the same level of systems science as the student teachers in the technical course, but they mostly used only one case example. They had less opportunity to practice systems thinking autonomously and to transfer their knowledge to other domains. Furthermore, they evaluated system models only slightly and reflected a little on the validity and limits of the models. However the Mixed Course included sessions on conceptualizations of systems thinking, on a competence model, teaching methods, and pupils' preconceptions. The participants in this course had little time to work with the teaching methods or to practice, reflect, and to integrate them in planned lessons.

\section{Results}

We analyzed student teachers' notes by using a coding scheme according to Mayring (2007). We derived criteria for correct notes from the critical aspects described. On the basis of this coding scheme, three trained student assistants and the first author categorized the notes. Every correct comment was scored 1 and false answers were scored 0 . Thus, the scoring ranged from 0 to a maximum of score of 6 . After a few codings and some adaption of the coding scheme, we reached an acceptable interrater reliability (Krippendorff's alpha over .80; Hayes \& Krippendorff, 2007). With the sum score added by all correct notes, we used the statistical software IBM SPSS v.22 for Windows for further analysis. This analysis belongs to the statistical mixed-methods analysis and represents a hybrid analysis using qualitative and quantitative methods.

The reliability marks the precision of the measurement instrument, but due to the limited number of items, the calculation of the internal consistency with Cronbach's $\alpha$ (Cronbach, 1951) is not meaningful (Schmitt, 1996). Another way to measure the reliability is through repeated testing. An reliable instrument should highly correlate with the previous testing (Trochim, 2000). In the present study, the correlation between the second and the third measurement indicates a reliable measurement $\left(r=.583^{* *}\right)$. Expected correlations between this instrument and the paper and pencil measurements of declarative CK in teaching systems thinking ( $r=.313^{* *}$; Fanta et al., 2016) and the declarative PCK in teaching systems thinking ( $r=.488^{* *}$; Rosenkränzer Stahl, et al., 2016) were observed (convergent validity) but indicate a different form of knowledge measured (Trochim, 2000).

Descriptive statistics were generated and the data were verified to be normally distributed. To analyze whether the experiment's four conditions differ a priori in the dependent variable (sum score of the reflective CRK in teaching systems thinking), we tested the assumption of equal variances by computing Levene's test. An univariate analysis was performed with the reflective CRK at time $t 1$ and the independent variable "experimental condition" (Brown \& Forsythe, 1974). The results of the test showed no significant difference between the four groups, $F(3,104)=2.24, p=.07$. Nevertheless, given that the analysis showed some meaningful difference close to the significance level, we decided to adjust for differences by performing analyses of covariate (ANCOVA) in further tests.

\section{(1) Is there an intervention effect in student teachers' reflective CRK in evaluating a lesson with the goal of} fostering systems thinking?

We assessed student teachers' reflective CRK in evaluating a lesson with the goal of fostering systems thinking at three temporal measurement points. On average, the student teachers could identify only one of the six mistakes in the video before the intervention; $M=1.25(S D=1.08)$. After the intervention student teachers found more mistakes $M=1.77(S D=1.42)$ but without any statistical significances $F(3,103)=2.34 ; p=.08$. In follow up test $M=1.67$ ( $S D=1.14)$, a significant improvement in student teachers CRK for teaching systems thinking was measured, $F(3,103)=4.916, p=.003, \eta^{2}=.125$. Looking at the data in more detail (see Table 2), we found the improvement was mainly in the knowledge form of student teachers CK for teaching systems thinking. As in the pretest, only 8 of 71 student teachers in the intervention courses noted that the definition of a system was incorrect in the video and 13 student teachers were able to identify the incorrect definition after the intervention (follow-up: 12). The second CK aspect was noted by 17 participants in the pretest, and 26 student teachers were able to identify the incorrect labels of the connections and interaction in the posttest. In the follow-up test, the number increased a little to 28 . Before the intervention, only 5 students noted that the teacher in the videotaped lesson showed the complexity of a system mainly as a food web, whereas 17 student teachers identified this aspect after the intervention. Remarkably, the number of participants who noted this aspect nearly halved to only 9 in the follow-up test. 
Table 2. Identification rate of teacher's CK errors in the video across three test periods

\begin{tabular}{lccc}
\hline Type of CK error & pretest (t1) & posttest (t2) & follow-up test (t3) \\
\hline Incorrect definition of a system & $8(11 \%)$ & $13(18 \%)$ & $12(17 \%)$ \\
Incorret labeling of the connections and interactions & $17(24 \%)$ & $26(37 \%)$ & $28(39 \%)$ \\
System complexity is demonstrated mainly as a food web & $5(7 \%)$ & $17(24 \%)$ & $9(13 \%)$ \\
\hline
\end{tabular}

Furthermore, the data revealed that the identified mistakes in teachers' PCK for teaching systems thinking remained nearly unchanged across the three test periods. Only the third aspect (planned goals are not achieved) revealed an improvement. After the intervention, more student teachers were able to note that the teacher had assumed the pupils' knowledge in systems thinking (18) than in the pretest (3).

Table 3. Identification rate of teacher's PCK errors in the video across three test periods

\begin{tabular}{|c|c|c|c|}
\hline Types of PCK error & pretest (t1) & posttest (t2) & follow-up test (t3) \\
\hline $\begin{array}{l}\text { Assumption that the pupils know the term system in ecological } \\
\text { sciences }\end{array}$ & $6(8 \%)$ & $3(4 \%)$ & $1(1 \%)$ \\
\hline $\begin{array}{l}\text { Confusing map with many labeled connections and interactions on the } \\
\text { board }\end{array}$ & $50(70 \%)$ & $49(69 \%)$ & $51(72 \%)$ \\
\hline The planned goals are not achieved & $3(4 \%)$ & $18(25 \%)$ & $18(25 \%)$ \\
\hline
\end{tabular}

\section{(2) Are there identifiable differences in the intervention courses?}

Which seminar is most effective in promoting student teachers' reflective CRK in evaluating a lesson with the goal of fostering systems thinking?

To test statistically which of the four experimental conditions was most effective for increasing student teachers' reflective CRK in evaluating a lesson with the goal of fostering systems thinking, we computed $t$-tests for analyzing the data between different measurements within each group. The analysis of each group are shown in Table 4 for the posttest and in Table 5 for the follow-up test. Cohen's $d$ estimates of effect sizes ranged from 0.20 to 0.52 , suggesting that the treatment had a small effect (Cohen, 1988).

Table 4. Pretest and postest mean comparisons of student teachers' CRK

\begin{tabular}{|c|c|c|c|c|c|c|}
\hline & $\begin{array}{l}\text { pretest } \\
\text { M (SD) }\end{array}$ & $\begin{array}{l}\text { posttest } \\
\text { M (SD) }\end{array}$ & $\begin{array}{l}\text { gain } \\
\text { M (SD) }\end{array}$ & $\mathbf{T}$ & $\mathbf{p}$ & $\begin{array}{l}\text { effect } \\
\text { size d }\end{array}$ \\
\hline Control Group & $0.90(0.83)$ & $1.06(0.97)$ & $0.16(0.14)$ & 0.96 & .343 & 0.20 \\
\hline (1) Technical Course & $0.78(0.85)$ & $1.26(1.32)$ & $0.38(0.34)$ & 1.42 & .171 & 0.44 \\
\hline (2) Didactic Course & $1.60(1.25)$ & $2.16(1.52)$ & $0.56(0.31)$ & 1.83 & .080 & 0.40 \\
\hline (3) Mixed Course & $1.36(0.93)$ & $1.87(1.32)$ & $0.51(0.23)$ & 2.23 & .036 & 0.48 \\
\hline
\end{tabular}

Table 5. Pretest and follow-up mean comparisons of student teachers' CRK

\begin{tabular}{|c|c|c|c|c|c|c|}
\hline & $\begin{array}{l}\text { pretest } \\
\text { M (SD) }\end{array}$ & $\begin{array}{l}\text { follow-up } \\
\text { M (SD) }\end{array}$ & $\begin{array}{l}\text { gain } \\
\text { M (SD) }\end{array}$ & $\mathbf{T}$ & $\mathbf{p}$ & $\begin{array}{l}\text { effect } \\
\text { size d }\end{array}$ \\
\hline Control Group & $0.90(0.83)$ & $0.89(0.70)$ & $0.03(0.11)$ & 0.24 & .812 & 0.00 \\
\hline (1) Technical Course & $0.78(0.85)$ & $1.22(0.90)$ & $0.44(0.27)$ & 1.64 & .116 & 0.49 \\
\hline (2) Didactic Course & $1.60(1.25)$ & $1.92(1.26)$ & $0.32(0.28)$ & 1.14 & .266 & 0.24 \\
\hline (3) Mixed Course & $1.36(0.93)$ & $1.88(1.14)$ & $0.52(0.25)$ & 2.08 & .049 & 0.52 \\
\hline
\end{tabular}


The Mixed Course, which combined technical and subject-related didactic content in almost equal proportions, is the only experimental condition that achieved a significant increase of student teachers' reflective CRK in the posttest, $t(22)=2.23, \mathrm{p}=.036, d=0.48$, and in the follow-up test, $t(22)=2.08 ; p=.049 ; d=0.52$. Figure 6 illustrates the results of each group.

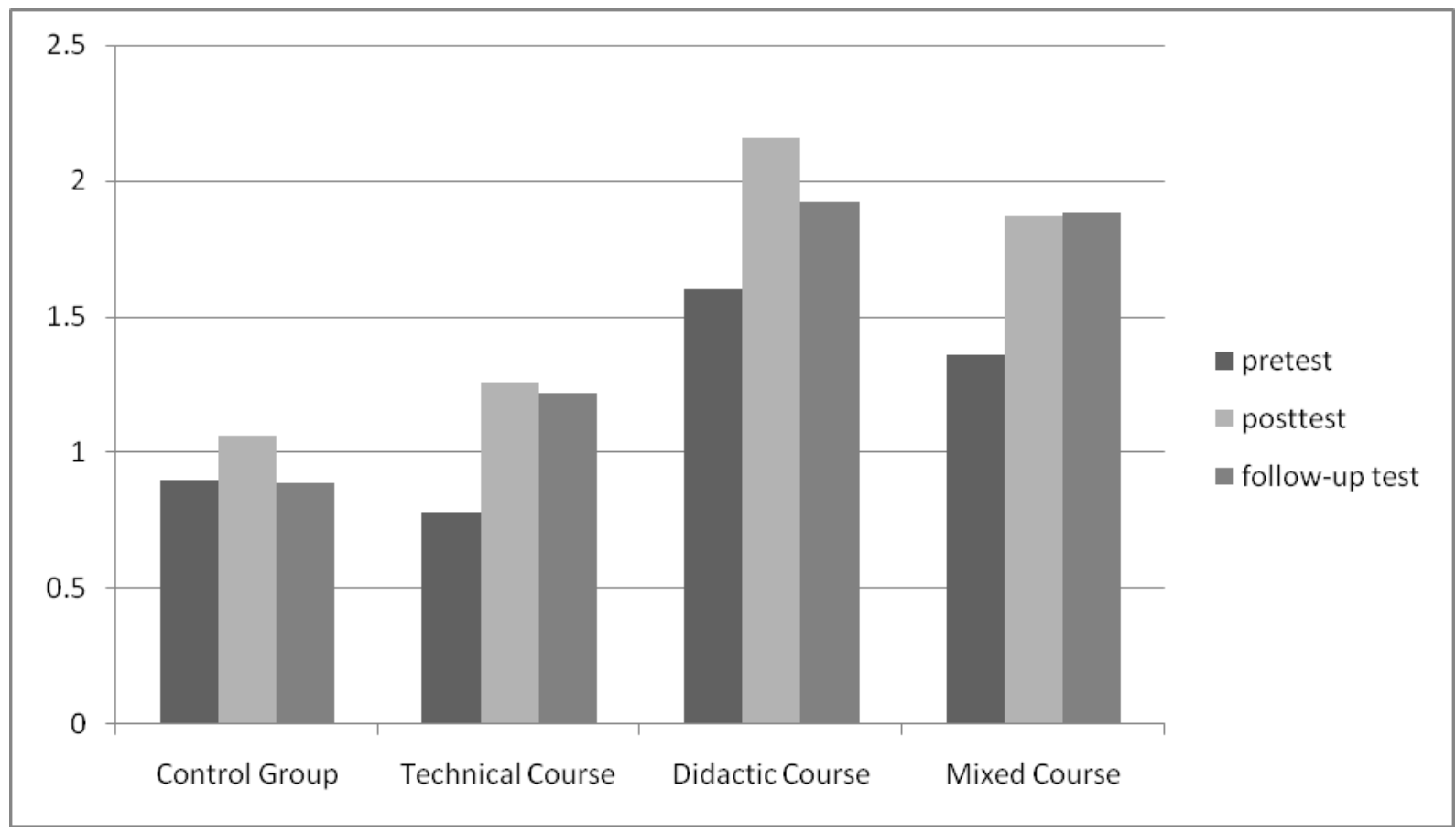

Figure 6. Results of the treatment groups

\section{Discussion}

"Education is critical for promoting sustainable development and improving the capacity of the people to address environment and development issues" (UNCED, 1992). Notwithstanding, knowledge of the dynamics and complexity of living systems in biology and geography does not ensure that teachers know how systems thinking can be fostered in pupils.

In an intervention during the summer term 2013, 71 student teachers were trained in different forms of knowledge for teaching systems thinking. The intervention contained three varied courses: 1) a course that focussed on promoting mainly CK for teaching systems thinking, 2) a course that focussed on promoting mainly PCK for teaching systems thinking, and 3) a course that promoted both CK and PCK aspects for teaching system thinking in equal parts.

The use of videos to capture student teachers' CRK allows not only the measurement of declarative knowledge but also the measurement of knowledge in action, e.g., procedural knowledge and reflective knowledge. In the pretest analysis, we found just a very low level of student teachers' CRK in teaching systems thinking. These results are in line with the measurement of student teachers' PCK in the other subsurveys of our larger study (Rosenkränzer et al., 2016).

The results show an improvement after the intervention by adjusting the pretest score as a covariate. In the posttest analysis, the results failed the significance test marginally, but in the follow-up test a significant difference emerged, albeit with a low effect size. A similar pattern of results occurered in the category analysis of CRK, that is, an increase in student teachers' reflective CK and PCK for teaching systems thinking. Following the results of Oser, Salzmann and Heinzer (2009), declaring video as an effective measurement instrument for assessing teachers' work, we imply an effective intervention in promoting teachers' reflective CRK for teaching systems thinking. The intervention is also consistent with the aims of AGENDA 21 by promoting systems thinking in science teacher education. 
A further goal of our study was to find the most effective intervention course. In teacher education, one important ongoing debate is about an adequate CK and PCK base for upcoming teachers. Researchers argue very differently over the extent of technical and didactic input (Ball et al., 2005; Borko \& Putnam, 1996; Krauss et al., 2006; Kunter \& Baumert, 2013). The findings from our study suggest that the Mixed Course with an equal proportion of technical and didactic content will achieve significant improvement.

Nonetheless, the study has limitations, and caution should be taken to not overgeneralise the findings. Although the sample size in each experimental group is relatively small $(n<30)$, the inessential need to randomly assign student teachers to experimental courses allows for an improvement in future experimental designs. Another limitation is the collection and analysis of the qualitative data. Student teachers' reflective CRK was obtained from their notes, and transforming qualitative dato to quantitative data could have produced errorneous results, although our method is based on current statistical methods.

This study employed digital media to assess teaching sequences in action as a method to improve teacher's knowledge in education. Given the current available options in digital media, traditional research in teacher education using pen and paper surveys may no longer be an effective means for measuring the complex use of teachers' professional knowledge in action. Thus, we encourage future research in teacher education to not only use pen and paper tests but also digital media to capture teachers CRK and to uncover the complexity of teachers' actions in the classroom. Finally, we hope that the empirical evidence provided by our study will inform these discussions.

\section{References}

Abell, S. K. (2007). Research on science teacher knowledge. In S. K. Abell (Ed.), Handbook of research on science education (pp. 1105-1149). Mahwa, NJ: Lawerence Erlbaum Associates.

Ball, D. L., Hill, H. H., \& Bass, H. (2005). Knowing mathematics for teaching. American Educator, 14-46.

Ball, D. L., Lubienski, S. T., \& Mewborn, D. S. (2001). Research on teaching mathematics. The unsolved problem of teachers' mathematical knowledge. In V. Richardson (Ed.), Handbook of research on teaching (pp. 433-456). New York: Macmillan.

Baumert, J., Kunter, M., Blum, W., Brunner, M., Voss, T., Jordan, A. Klusmann, U., ..., Tsai, Y. M. (2009). Teachers' mathematical knowledge, cognitive activation in the classroom, and student progress. American Educational Research Journal, 47(1), 133-180. https://dx.doi.org/10.3102/0002831209345157

Ben-Zvi Assaraf, O., \& Orion, N. (2005). Development of system thinking skills in the context of earth system education. Journal of Research in Science Teaching, 42(5), 518-560. https://dx.doi.org/10.1002/tea.20061

Bertalanffy, L. V. (1968). General system theory: Foundations, development, applications. New York: Braziller.

Borko, H., \& Putnam, R. T. (1996). Learning to teach. In D. C. Berliner, \& R. C. Calfee (Eds.), Handbook of educational psychology (pp. 673-708). New York: Macmillan.

Borowski, A., Carlson, J., Fischer, H., Gess-Newsome, J., Henze, I., Kirschner, S., \& Van Driel, J. (2012). Different models and methods to measure teachers' pedagogical content knowledge. In P. Daugbjerg (Ed.), Science teachers' narratives on motivation and commitment: A story about recruitment and retention. Paper presented at European Science Education Research Association, Lyon, France.

Bossel, H. (2007). Systems and models: Complexity, dynamics, evolution, sustainability. Norderstedt: Books on Demand.

Bräutigam, J. (2014). Systemisches Denken im Kontext einer Bildung für nachhaltige Entwicklung. Konstruktion und Validierung eines Messinstruments zur Evaluation einer Unterrichtseinheit [Systems thinking in context of sustainable development. development and validation of a measurement instrument for evaluating a lesson] (Dissertation). Pädagogische Hochschule Freiburg.

Bromme, R. (2008). Lehrerexpertise [Teacher's expertise]. In M. Schneider, \& M. Hasselhorn (Eds.), Handbuch der Pädagogischen Psychologie (pp. 159-167). Göttingen: Hogrefe.

Brown, M. B., \& Forsythe, A. B. (1974). Robust tests for equality of variances. Journal of the American Statistical Association, 69(346), 364-367. https://dx.doi.org/10.1080/01621459.1974.10482955

Cohen, J. (1988). Statistical power analysis for the behavioral sciences (2nd ed.). Hillsdale, NJ: Lawrence Erlbaum Associates.

Cronbach, L. J. (1951). Coefficient alpha and the internal structure of tests. Psychometrika, 16, 297-334. https://dx.doi.org/10.1007/BF02310555 
De Jong, T., \& Ferguson-Hessler, M. (1996). Types and qualities of knowledge. Educational Psychologist, 31(2), 105-113. https://dx.doi.org/10.1207/s15326985ep3102_2

Evagorou, M., Korfiatis, K., Nicolaou, C., \& Constantinou, C. (2009). An investigation of the potential of interactive simulations for developing system thinking skills in elementary school: A case study with fifth-Graders and sixth-Graders. International Journal of Science Education, 31(5), 655-674. https://dx.doi.org/10.1080/09500690701749313

Fanta, D., Bräutigam, J., \& Riess, W. (2016). Teaching systems thinking: Evaluating an intervention for biology and geography university students. Manuscript in preparation.

Fischer, H., Borowski, A., \& Tepner, O. (2012). Professional Knowledge of Science Teachers. In B. J. Fraser, K. Tobin, \& C. J. McRobbie (Eds.), Second International Handbook of Science Education. Springer Science+Business Media B.V. https://dx.doi.org/10.1007/978-1-4020-9041-7_30

Grossman, P. (1990). The making of a teacher: Teacher knowledge and teacher education. New York: Teacher College Press.

Großschedl, J., Mahler, D., Kleickmann, T., \& Harms, T. (2014). Content-related knowledge of biology teachers from secondary schools: Structure and learning opportunities. International Journal of Science Education, 36(14), 1-32. https://dx.doi.org/10.1080/09500693.2014.923949

Hashweh, M. (2005). Teacher pedagogical constructions: A reconfiguration of pedagogical content knowledge. Teachers and Teaching: Theory and Practice, 11(3), 273-292. https://dx.doi.org/10.1080/13450600500105502

Hattie, J. (2009). Visible learning: A synthesis of over 800 meta-analyses relating to achievement. London, New York: Routledge.

Hayes, A. F., \& Krippendorff, K. (2007). Answering the call for a standard reliability measure for coding data. Communication Methods and Measures, 1(1), 77-89. https://dx.doi.org/10.1080/19312450709336664

Jelemenská, P., \& Kattmann, U. (2008). Understanding the units of nature: From reification to reflection. A contribution to Educational Reconstruction in the field of ecology. In M. Hammann, M. Reiss, C. Boulter, \& S. D. Tunnicliffe (Eds.), Biology in Context. Learning and teaching for the twenty-First century (pp. 29-39). London: University of London.

Kramer, T. (2016). Die Flexibilität epistemologischer Urteile von Lehrenden und Lehramtsstudierenden [Versality of teachers' and student teachers' epistemological judgements]. Manuscript in preparation.

Krauss, S., Brunner, M., Kunter, M., Baumert, J., Neubrand, M., Blum, W., \& Jordan, A. (2008). Pedagogical content knowledge and content knowledge of secondary mathematics teachers. Journal of Educational Psychology, 100(3), 716-725. https://dx.doi.org/10.1037/0022-0663.100.3.716

Kropp, J. P., Eisenack, K., \& Scheffran, J. (2006). Marine overexploitation: A syndrome of global change. In S. Sonak (Ed.), Multiple Dimensions of Global Change (pp. 257-284). New Delhi: TERI press.

Kunter, M., \& Baumert, J. (2013). The COACTIV research program on teachers' professional competence: Summary and discussion. In M. Kunter, J. Baumert, W. Blum, U. Klusmann, S. Krauss, \& M. Neubrand (Eds.), Cognitive activation in the mathematics classroom and professional competence of teachers. Results from the COACTIV project (pp. 345-368). New York, NY: Springer. https://dx.doi.org/10.1007/978-1-4614-5149-5_18

Magnusson, S., Krajcik, J., \& Borko, H. (1999). Nature, sources and development of pedagogical content knowledge for science teaching. In J. Gess-Newsome, \& N. G. Lederman (Eds.), Examining pedagogical content knowledge: The construct and its implications for science education (pp. 95-132). Boston: Kluwer.

Matthies, M., Malchow, H., \& Kriz, J. (2001). Integrative systems approaches to natural and social dynamics. Heidelberg: Springer. https://dx.doi.org/10.1007/978-3-642-56585-4

Mayring, P. (2007). Mixing qualitative and quantitative methods. In P. Mayring, G. L. Huber, L. Gürtler, \& M. Kiegelmann (Eds.), Mixed methodology in psychological research (pp. 27-36). Rotterdam: Sense Publishers.

Oser, F., Salzmann, P., \& Heinzer, S. (2009). Measuring the competence-quality of vocational teachers: An advocatory approach. Empirical Research in Vocational Education and Training, 1, 65-84. 
Park, S., \& Oliver, S. J. (2008). Revisiting the conceptualization of Pedagogical Content Knowledge (PCK): PCK as a conceptual tool to understand teachers as professionals. Research in Science Education, 38(3), 261-284. https://dx.doi.org/10.1007/s11165-007-9049-6

Peterson, R., \& Treagust, D. (1995). Developing preservice teachers' pedagogical reasoning ability. Research in Science Education, 25, 291-305. https://dx.doi.org/10.1007/BF02357403

Rempfler, A., \& Uphues, R. (2011). Systemkompetenz und ihre Förderung im Geographieunterricht [Systems competencies and its promotion in geography lessons]. Geographie und Schule, 189(33), 22-33.

Riess, W., \& Mischo, C. (2016). Bridging the gap "Zur Verringerung der Kluft zwischen allgemeinen Lehr-Lernmodellen und konkreter Unterrichtsgestaltung am Beispiel der Förderung dynamischer Problemlösekompetenz in der Biologie (Manuscript submitted for publication).

Riess, W., \& Mischo, C. (2010). Promoting systems thinking through biology lessons. International Journal for Science Education, 32(6), 705-725. https://dx.doi.org/10.1080/09500690902769946

Riess, W., Schuler, S., \& Hörsch, C. (2015). Wie lässt sich systemisches Denken vermitteln und fördern? Theoretische Grundlagen und praktische Umsetzung am Beispiel eines Seminars für Lehramtsstudierende. [How can systems thinking be teached and promoted? Theoretical foundations and practical uses in a exemplary course for student teachers]. Geographie aktuell und Schule, 37(215), 16-24.

Rosenkränzer, F., Kramer, T., Hörsch, C., Schuler, S., \& Riess, W. (2016). Student teachers' Pedagogical Content Knowledge (PCK) for teaching systems thinking: Effects of an intervention (Manuscript submitted for publication).

Rosenkränzer, F., Stahl, E., Hörsch, C., Schuler, S., \& Rieß, W. (2016). Das Fachdidaktische Wissen von Lehramtsstudierenden zur Förderung von systemischem Denken: Konzeptualisierung, Operationalisierung und Erhebungsmethode [Student teachers Pedagogical Content Knowledge for teaching systems thinking: Conceptualization, operationalization and measurement]. Zeitschrift für Didaktik der Naturwissenschaften, $1-13$.

Schellnhuber, H. J., Block, A., Cassel-Gintz, M., Kropp, J., Lammel, G., Lass, W., ... Reusswig, F. (1997). Syndromes of Global Change. GAIA, 6(1), 19-34.

Schmelzing, S., van Driel, J., Jüttner, M., Brandenbusch, S., Sandmann, A., \& Neuhaus, B. (2013). Development, evaluation, and validation of a paper-an-pencil test for measuring two components of biology teachers' pedagogical content knowledge concerning the "cardiocascular system". International Journal of Science and Mathematics Education, 11, 1369-1390. https://dx.doi.org/10.1007/s10763-012-9384-6

Schmitt, N. (1996). Uses and abuses of coefficient alpha. Psychological Assessment, 8(4), 350-353. https://dx.doi.org/10.1037/1040-3590.8.4.350

Schuler, S. (2012). Denken lernen mit Mystery-aufgaben [Promoting thinking with mystery tasks]. In Praxis Geographie extra: Mystery. Geographische Fallbeispiele entschlüsseln. Braunschweig: Westermann.

Seidel, T., \& Prenzel, M. (2007). Wie Lehrpersonen Unterricht wahrnehmen und einschätzen—erfassung pädagogisch-psychologischer Kompetenzen mit Videosequenzen [How teacher look at lessons and evaluate them-Measuring pedagogical and psychological competencies with videos]. Zeitschrift für Erziehungswissenschaften, 8, 201-216.

Shadish, W. R., Cook, T. D., \& Campbell, D. T. (2002). Experimental and quasi-experimental designs for generalized causal inference. Boston: Houghton Mifflin.

Sherin, M. G., \& van Es, E. A. (2009). Effects on video club participation on teachers' professional vision. Journal of Teacher Education, 60(1), 20-37. https://dx.doi.org/10.1177/0022487108328155

Shulman, L. (1986). Those who understand: Knowledge growth in teaching. Educational Researcher, 15(2), 4-14. https://dx.doi.org/10.3102/0013189X015002004

Shulman, L. S. (1987). Knowledge and teaching of the new reform. Harvard Educational Review, 57, 1-22. https://dx.doi.org/10.17763/haer.57.1.j463w79r56455411

Todorova, M., Sunder, C., Steffensky, M., \& Möller, K. (2014). Videobasiertes Lernen in der naturwissenschaftsbezogenen Grundschullehrerbildung [Video-based learning in science teacher education for primary school]. In GEBF Jahrestagung 2014. Frankfurt am Main.

Trochim, W. (2000). The research methods knowledge base (2nd ed.). Cincinnati: Atomic Dog Publishing. 
UNCED. (1992). Agenda 21: Program of action for sustainable development. United Nations conference of environment and development, Rio de Janeiro, Brazil. Retrieved from https://sustainabledevelopment.un.org/content/documents/Agenda21.pdf

Van Driel, J., Verloop, N., \& De Vos, W. (1998). Developing science teachers' pedagogical content knowledge. Journal of Research in Science Teaching, 673-695. https://dx.doi.org/10.1002/(SICI)1098-2736(199808)35:6<673::AID-TEA5>3.0.CO;2-J

Verhoeff, R. P. (2003). Towards systems thinking in cell biology education. Utrecht: CD- $\beta$ Press.

\section{Copyrights}

Copyright for this article is retained by the author(s), with first publication rights granted to the journal.

This is an open-access article distributed under the terms and conditions of the Creative Commons Attribution license (http://creativecommons.org/licenses/by/4.0/). 